\title{
由烃加工到烃合成: 催化技术进展
}

\author{
金中豪 ${ }^{1}$, 周海波 ${ }^{1}$, 王仰东 ${ }^{1^{*}}$, 谢在库 $2^{*}$ \\ 1. 中国石油化工股份有限公司上海石油化工研究院, 上海 201208; \\ 2. 中国石油化工股份有限公司，北京 100027 \\ * 联系人, E-mail: wangyd.sshy@ sinopec.com; xzk@ sinopec.com
}

2018-04-10 收稿, 2018-05-23 修回, 2018-06-04 接受, 2018-06-26 网络版发表

摘要烃类化合物是构成液体燃料和合成材料单体的重要化学品, 面对资源和环境的双重挑战, 传统的烃类生 产技术已不能满足经济发展需求。本文分析了由烃加工到烃合成技术发展趋势，综述了烃加工和烃合成对催化新 技术的需求, 提出烃加工要围绕石油资源高效利用与绿色清洁转化技术, 烃合成要发展甲醇及合成气等碳一转化 技术，进而推进煤、天然气高效清洁利用，同时要发展生物质资源转化及可再生能源的利用技术，最终实现碳循 环. 通过分析总结典型催化案例, 阐述了“系统与基元”、“表观与本征”等烃加工到烃合成催化技术的关键科学 问题.

关键词烃加工, 烃合成, 催化材料, 催化反应工艺

作为主要能源产品的油品与合成材料(塑料、橡 胶及纤维)单体的烯烃、芳烃等烃类产品的生产是国 民经济的支柱, 与人民生活息息相关. 烃加工是指通 过对石油的馏分分离或化学转化生产不同结构组成 的烃类产品, 如石油炼制的油品和石油化工的烯烃 芳烃等, 是由大分子烃自上而下(top-down)裁剪转化 为目标烃产品的制烃路线, 包含了碳碳键裂解和定 向剪裁等一系列化学转化反应, 涵盖了石油炼制和 石油化工主要过程, 是当前烃产品主要生产途径, 如 图1所示 ${ }^{[1]}$.

从长远看, 石油资源短缺趋势不可避免, 页岩气 革命也给全球能源经济带来新的选择, 发展新的烃 合成技术已成为重要方向. 烃合成是以煤、天然气及 生物质等非石油基资源为原料, 经碳一或低碳平台, 如合成气、甲醇、糖平台化合物, 通过碳碳键偶联及 碳链增长等化学转化制备烃类. 烃合成路线是由碳 一等小分子自下而上(bottom-up)组装转化为目标烃 产品的制烃路线, 涵盖了新型煤化工与天然气化工
的主要过程，也是未来生物质转化及可再生能源 产业的重要组成, 是当前及未来烃产品生产的重要 补充.

随着资源与环境对经济社会发展的制约日益苛 刻, 能源与化工产业绿色可持续发展更为迫切, 烃类 产品生产技术发展方向更加明确：一是提升石油资 源的利用效率, 以降低能耗及碳排放为目标, 发展新 一代绿色高效的烃加工技术; 二是开拓基于非石油 资源的碳一转化等烃合成新技术途径, 满足经济发 展对能源与合成材料的需求.

当前, 以开发碳一及生物质转化新途径的烃合 成若干技术研发已成为国际化学化工领域的热点课 题, 也是国际大型能源公司关注的重大技术创新方 向, 同时, 绿色高效的烃加工技术也不断取得重要进 展 $^{[2 \sim 5]}$. 其中, 催化材料与技术的突破正是烃加工和 烃合成技术创新的关键. 本文从烃加工到烃合成催 化技术发展角度, 对其技术需求及相关催化科学问 题进行了综述和展望. 


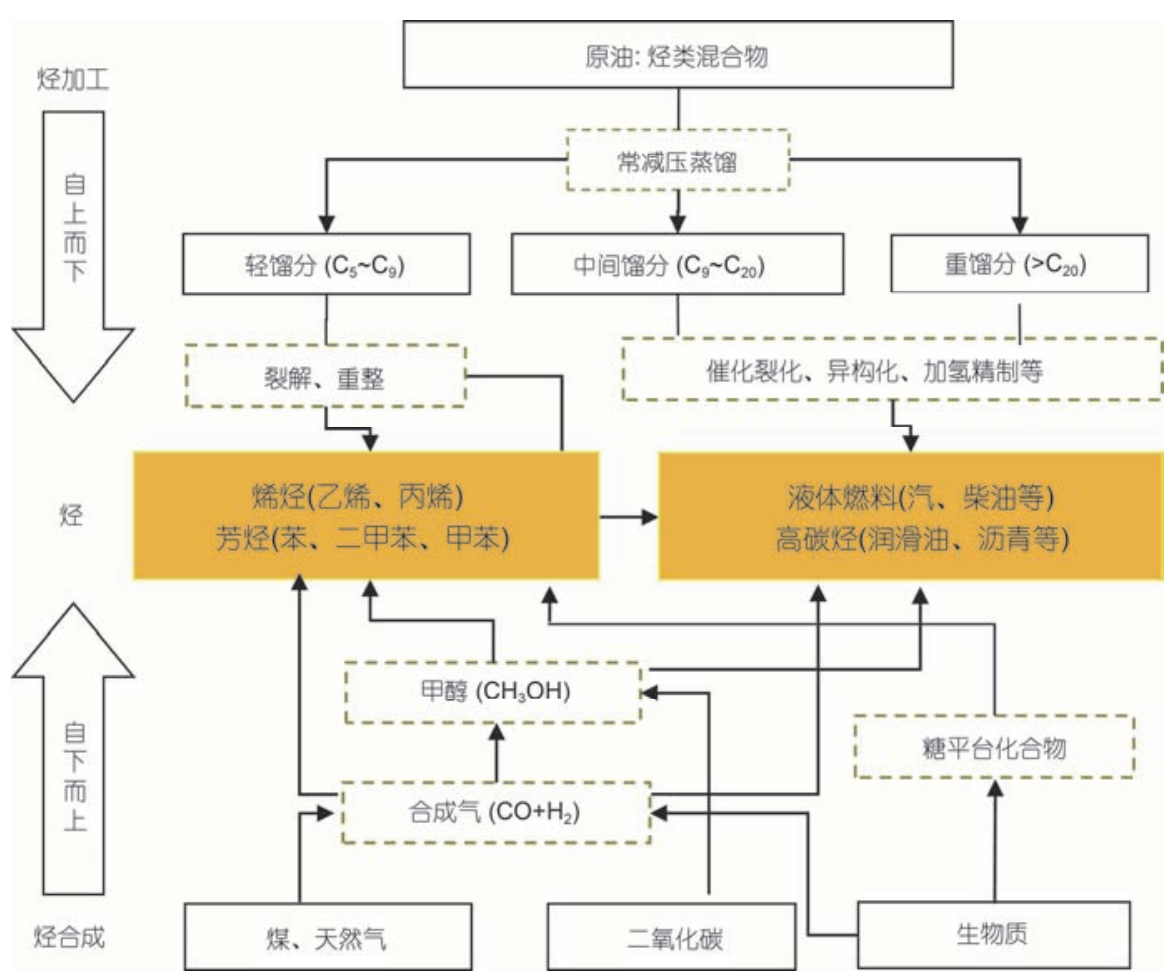

图 1 (网络版彩色)两类主要制烃技术: 烃加工路线与烃合成路线

Figure 1 (Color online) Two main pathways of hydrocarbon production: Hydrocarbon processing and hydrocarbon synthesis

\section{1 从烃加工到烃合成的重要催化技术进展}

\section{1 烃加工: 石油资源高效利用与绿色清洁转化}

烃加工路线主要涉及石油炼制和石油化工过程, 是将石油组分中的长链烃经物理分离或化学转化制 备油品、烯烃芳烃等烃类产品. 目前, 我国石油原料 重质化劣质化趋势严重、环境约束日益苛刻, 以重质 原油炼制生产清洁油品和石化 $\mathrm{C}_{4} / \mathrm{C}_{5}$, 重芳烃副产提 值转化是绿色高效烃加工催化技术创新的重要方向.

重质油炼制生产清洁油品面临的问题是其稠环 芳烃含量高、分子尺寸较大, 分子篎催化材料的孔道 调控及多级孔构建可促进其高效转化. 作为炼油工 业发展的里程碑，Y型分子篎成功合成并以此发展了 流化床催化裂化(FCC)炼油技术. 近年来, 针对重质 油加工, 促进大分子烃原料转化, 克服分子篮对大分 子烃的扩散限制, 提高分子篮孔道内活性中心的可 接近性, 创制了复合孔分子篮, 并已在炼油催化中获 得应用, 如图 2 所示 ${ }^{[6]}$. Meng等人 ${ }^{[7]}$ 采用原位包裹策 略, 制备了外层被无定型硅铝凝胶 (ASA) 包覆的 Y/ASA复合物, 与常规物理混合相比, 该型催化剂具 有利于扩散的规整多级孔道结构, Y型分子篮与ASA
键合形成新的酸性位促进了正癸烷高选择性转化为 中间馏分油. Jiao等人 ${ }^{[8]}$ 利用纳米粒子表面的静电作 用，将氧化铝纳米棒包覆在分子篮外表面从而构筑 多级结构的 $\mathrm{Y} @ \gamma-\mathrm{Al}_{2} \mathrm{O}_{3}$ 核壳材料, 形成了多级孔道结 构以及梯度分布的酸中心，促进了油品大分子烃的 扩散与裂化. Sachse和 Garcia-Martinez ${ }^{[9]}$ 采用阳离子 表面活性剂辅助后处理Y分子篮，在保持分子篮微孔 结构的同时引人规整的晶内介孔，提高了重质油裂 化效率, 减少塔底物的残留, 提高了汽油组分收率, 并抑制了催化剂积炭. 这些催化材料优异的重油 FCC 催化性能都可归功于反应物分子高效扩散的核 壳结构或多级孔道体系。

重油、渣油加氢处理技术不仅能有效提高原料油 的碳利用率，并能调变产物的碳氢比，提高目标产物 的选择性及生产方案的灵活性. 在该领域中, 开发具 有梯度孔径和酸中心分布的分子篮材料仍是重要的 技术手段 ${ }^{[10,11]}$. 与常规改性Y型分子篮相比，介孔 Y/Al-SBA-15负载W-Ni后在重油加氢裂解反应中表 现出更高的柴油产率，以及高的重石芳潜和极低的 尾油BMCI值 ${ }^{[12]}$.

利用 $\mathrm{C}_{4} / \mathrm{C}_{5}$ 副产的烯烃催化裂解生产乙烯、丙烯 


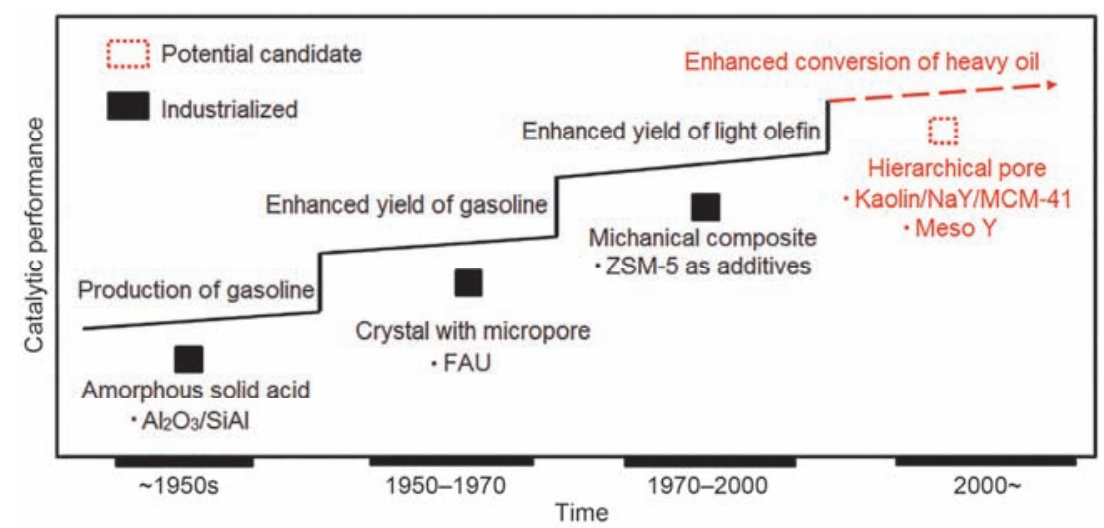

图 2 (网络版彩色)分子笁孔道结构调变是提高FCC反应催化效率的主要手段 ${ }^{[6]}$

Figure 2 (Color online) Modulating the channel structure of molecular sieve is the primary means of improving the catalytic efficiency in FCC ${ }^{[6]}$

技术是近年来发展的烃加工新技术 ${ }^{[13]} \cdot \mathrm{C}_{4} / \mathrm{C}_{5}$ 等短链 烃的裂解, 其反应苛刻度较高, 采用高酸性密度的 ZSM-5分子篮催化剂, 极易结焦造成催化剂失活, 提 高催化剂稳定性是该技术的关键. Mitchell等人 ${ }^{[14]}$ 合 成了一系列相同酸性的ZSM-5分子篮, 以2-甲基-2丁烯催化裂解制低碳烯烃为模型反应, 研究了尺寸、 形态、缺陷量和介孔性等分子篮晶体的结构性质对催 化剂稳定性和烯烃选择性的影响. 研究发现, 降低晶 体尺寸和/或引人晶内介孔能够增加中孔表面积, 在 不阻塞微孔的前提下提升抗积炭能力, 进而显著延 长催化剂寿命. 此外, 采用可控相分离-固相转晶的 复合孔分子篮合成新策略 (图 3), 也可有效促进 ZSM-5分子篮的扩散性能, 其催化活性及稳定性得 到大幅提高 ${ }^{[15,16]}$, 成功开发了 $\mathrm{C}_{4} / \mathrm{C}_{5}$ 烯烃催化裂解制 乙烯丙烯 $(O C C)$ 工艺, 实现工业应用.

节能和减排是绿色高效烃加工技术的另一重要 目标. 在乙苯和异丙苯等烷基苯催化合成中, 为提高 产品选择性和催化剂稳定性, 常采用高苯烯比工艺, 但该工艺产品分离能耗高, 适应低苯烯比工艺分子 篮催化材料的开发是该技术研发的重要目标. Mobil 公司开发了 MWW结构新型分子篮材料并应用于苯 烷基化过程, 大幅度降低了苯烯比, 减少了过量苯的 分离及循环, 降低了能耗, 这是由于 $\mathrm{MWW}$ 结构分子 篮具有层状结构和两种独立的十元环孔道体系(位于 层内的二维正弦孔道和层间的二维孔道), 层间十元 环孔道的开放“杯状” $12 \mathrm{MR}$ 超笼 $(0.71 \mathrm{~nm} \times 0.71 \mathrm{~nm} \times$ $1.82 \mathrm{~nm}$ )提供了烷基化反应场所, 其良好的扩散性能 更适合低苯烯比烷基化反应. 但是, MWW分子笁材 料在脱模板剂的热处理过程中, 层间硅羟基易发生

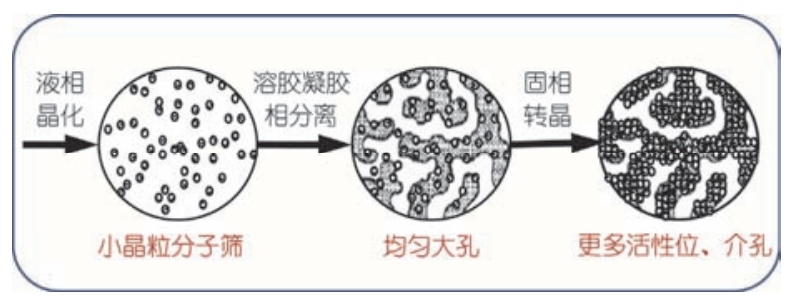

图 3 (网络版彩色)复合孔ZSM-5 分子篮催化材料合成策略

Figure 3 (Color online) The synthetic strategy of hierarchical ZSM-5 zeolite

缩合反应，导致层结构塌陷，将层间开放的“杯状孔” 转变为“封闭笼”, 反应物难以接近“封闭笼”中的酸催 化中心, 催化性能大幅下降. 如何合成单层的 MWW 结构分子篮材料对于提高其催化性能非常关键, 但 也存在巨大挑战. 高焕新课题组 ${ }^{[17]}$ 通过研究 MWW 分子篮晶化机理, 发展了“有机硅杂化层状分子篮” 合成策略, 在分子篮合成中原位嫁接有机硅烷, 插人 分子篮层间, 削弱了微晶表面间的相互作用, 诱导微 晶沿二维方向生长, 自发分层, 成功合成了具有单层 结构的 MWW结构分子篮SRZ-21(图4), 作为催化剂 用于苯与丙烯烷基化反应, 苯烯比可由 3.0 降至 2.0 , 建成 30 万吨/年异丙苯工业装置, 催化剂已连续稳定 运行超过 8 年.

\section{2 烃合成: 平台化合物及其可控转化}

甲醇转化平台技术是指由甲醇生产烯烃芳烃的 系列技术(图5). 最早的甲醇转化技术是Mobil公司开 发的甲醇制汽油技术(MTG), 在ZSM-5分子篮催化剂 作用下, 甲醇转化为汽油组分的长链烃化合物. 通过 对催化剂与反应工艺的不断优化, 发展了 $\mathrm{Mg}$ 改性 


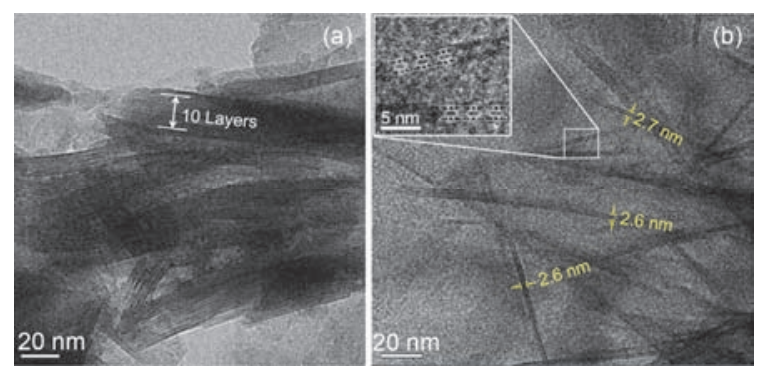

图 4 (网络版彩色)多层结构MCM-22 分子篮(a)和单层结构SRZ-21 分子篎(b)透射电子显微镜图

Figure 4 (Color online) TEM images of MCM-22 with multi-layer structure (a) and SRZ-21 with single-layer structure (b)

ZSM-5分子篮催化剂, 甲醇转化产物中低碳烯烃选 择性得到提高, 衍生出甲醇制烯烃技术(MTO). 20世 纪 80 年代, 环球油品公司 (UOP) 成功合成了新型 SAPO-34分子篮, 其更小的分子篮孔径更有利于甲 醇择形转化为乙烯、丙烯, 通过开发连续再生流化床 技术, 从反应工程角度克服了催化剂稳定性差的问 题. 由于中国煤炭资源清洁利用需求重大, MTO技术 的产业化在中国率先实现, 中国科学家做出了大量 的开创性贡献. 中国科学院大连化学物理所刘中民 团队 ${ }^{[18]}$ 开发的DMTO技术 2010 年率先工业化. 中国 石油化工集团公司随后也成功开发了全流程 S-MTO 技术, 相继实现了 60 万吨/年与世界最大 360 万吨/年 规模的工业应用. 目前, 流化床MTO技术单程双烯 (乙烯和丙烯)收率在 $80 \%$ 左右, 通过分子篮催化剂创 新和工艺组合仍存在进一步提高双烯收率的技术空 间, 同时根据乙烯和丙烯的需求变化, 调节乙烯/丙 烯产品比例也是催化研究的重要方向. S-MTO通过 组合OCC工艺, 双烯收率进一步增加 7\%, 显著提高 了MTO工艺的经济性 ${ }^{[19]}$. 目前, 国家能源集团、清华 大学、大唐国际发电股份有限公司等多个研究团队也 在持续开展MTO工业催化剂及工艺研究. 与此同时,
有更多的国内外研究小组正从事甲醇制烯烃基础研 究, 揭示甲醇制烯烃过程的碳碳键形成机制、烯烃生 成路径, 以及催化活性中心的烃池反应机理研究, 以 期通过机理准确阐述、催化材料进一步创新, 实现 MTO工业技术产物选择性调控、催化剂稳定性提高 等技术发展目标.

合成气 $\left(\mathrm{CO}\right.$ 和 $\left.\mathrm{H}_{2}\right)$ 是由煤、天然气、生物质转化 的重要平台化合物, 通过催化剂作用下的 CO加氢和 控制链增长, 选择性地合成烃, 以及醇、醛、酸等烃 类衍生物, 图6示出了合成气平台转化的主要路线.

由于产物分布服从Anderson-Schulz-Flory(ASF) 规则, 传统费托合成(FTS)的中间馏分产物选择性低, 甲烷选择性较高 ${ }^{[20]}$. 为突破ASF规则限制, 国内外研 究者开展了大量研究工作 ${ }^{[21 ~ 24]}$. 2016年, 中国科学院 上海高等研究院孙予罕领导的研究团队 ${ }^{[25]}$ 通过制备 棱柱状 $\mathrm{Co}_{2} \mathrm{C}$ 纳米颗粒催化剂, 实现了晶面调控, 选 择性暴露利于烯烃生成的 [101]晶面和抑制甲烷生成 的 [020]晶面. 在温和条件下, 合成气可高选择性转 化为低碳烯烃, 产物碳数呈现显著的窄区间分布, $\mathrm{C}_{2} \sim \mathrm{C}_{15}$ 选择性占 $90 \%$ 以上, 且表现出良好的稳定性. 这一突破性研究结果, 改变了 $\mathrm{Co}$ 催化剂低活性、利于 链增长的FTS反应传统观点, 具有启示作用.

长期以来, 开发非FTS合成气转化制烃类化合物 反应路线也是科研工作者持续追求的目标. 近期, 一 批中国科学家在此领域率先取得了重要突破. 2016 年, 中国科学院大连化学物理研究所包信和研究团 队 ${ }^{[26]}$ 提出了一种反应耦合的策略, 开发了双功能复 合的OX-ZEO(Oxide-Zeolite)催化剂 $\mathrm{ZnCrO}_{x} / \mathrm{M}$ SAPO(介孔SAPO分子篮), 不同于传统的FTS催化剂, 在反应过程中, OX-ZEO催化剂将合成气转化过程的 $\mathrm{CO}$ 活化与碳碳键偶联分开, $\mathrm{CO}$ 于 $\mathrm{ZnCrO}_{x}$ 表面活化生 成 $\mathrm{CH}_{2} \mathrm{CO}$ 中间体, 并在介孔 $\mathrm{SAPO}$ 分子篮的酸性限域

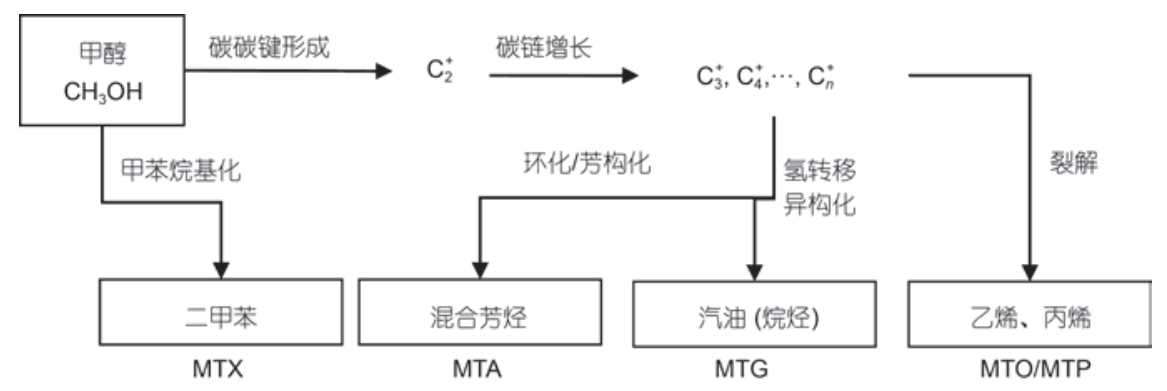

图 5 甲醇平台转化技术路线

Figure 5 The technical routes of methanol conversion platform 


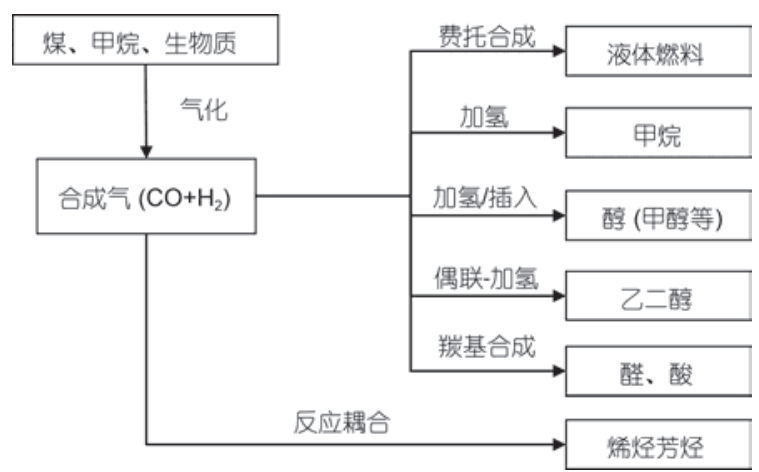

图 6 合成气平台转化技术路线

Figure 6 The technical routes of syngas conversion platform

孔道内进行碳碳键偶联, 从而得到了 $\mathrm{CO}$ 转化率 $17 \%$, 低碳烯烃选择性 $80 \%$, 甲烷选择性仅为 $2 \%$ 的反应结 果. 厦门大学的王野课题组 ${ }^{[27]}$ 同期报道了采用 $\mathrm{Zn}-\mathrm{Zr}$ 催化剂和 SAPO进行耦合, 得到了CO转化率 $11 \%$, $\mathrm{C}_{2} \sim \mathrm{C}_{4}$ 烯烃选择性 $74 \%$ 的反应结果. 2018 年, 包信和 课题组 ${ }^{[28]}$ 将 $\mathrm{ZnCrAl}$ 氧化物与 $\mathrm{MOR}$ 分子篮耦合, 实现 了 73\%的乙烯选择性. 基于以上研究思路, 合成气制 芳烃技术也取得了巨大的技术突破. 王野课题组 ${ }^{[29]}$ 报道将 $\mathrm{Zn}$ 掺杂 $\mathrm{ZrO}_{2}$ 与 $\mathrm{HZSM}-5$ 分子節耦合, 可实现合 成气直接转化制芳烃, $\mathrm{CO}$ 转化率、芳烃选择性分别达 到 20\%, 80\%, 催化剂寿命 $1000 \mathrm{~h}$ 以上. 同期, 包信和 课题组 ${ }^{[30]}$ 采用 $\mathrm{ZnCrO}_{x} / \mathrm{HZSM}-5$ 耦合催化体系, 得到 了CO转化率、芳烃选择性分别为 $16.0 \%, 73.9 \%$ 的研究 结果.

利用可再生的生物质资源转化制烃可减少碳的 排放 ${ }^{[31]}$. 考虑生物质制烃原料的来源, 油脂、微藻和 纤维素等非粮生物质是最适合用于替代化石资源生 产液体燃料和化学品等烃类产品的生物质资源, 主 要包括: (1) 生物油脂加氢脱羧; (2) 经平台化合物转 化; (3) 经生物热解油转化; (4) 经合成气平台转化等 制烃路线(图7).

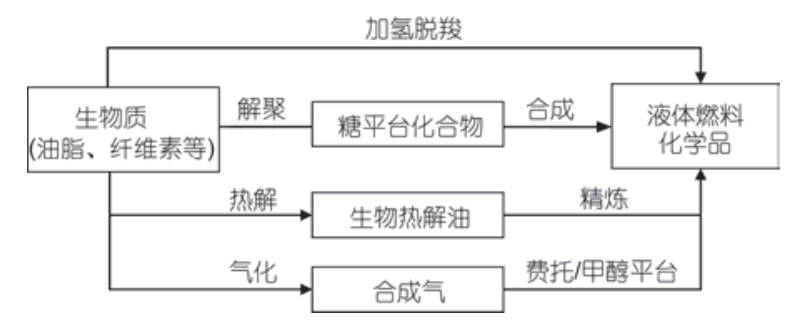

图 7 生物质转化制烃平台技术路线

Figure 7 The technical routes of biomass-to-hydrocarbon platform
近年来, 生物质纤维素解聚转化制备平台化合 物技术因其原料量大、产物附加值高等优点, 受到了 广泛的关注. 纤维素解聚可分为酶催化水解、化学催 化水解和催化氧化等方法, 根据解聚-反应程度不同, 产物包括纤维二糖、葡萄糖、乳酸、乙酸等多种平台 化合物及化学品. 但在酶解过程中, 纤维素会对纤维 素酶产生无效吸附, 降低酶的利用率, 提高成本. 邱 学青团队研究了长链脂肪醇对结晶纤维素酶水解反 应的影响 ${ }^{[32]}$, 发现长链醇可以将结晶纤维素的水解 效率从 $37 \%$ 提高到 $57 \%$, 并对与木质素或木聚糖混合 的结晶纤维素的酶水解亦具有类似的增强作用. 傅 尧课题组基于生物质制甲酸 ${ }^{[33]}$ 、乙酸 ${ }^{[34]}$ 等研究成果, 进一步开发了以生物质甲酸为碳源的非贵金属催化 胺甲基化反应，该方法利用非金属 Lewis酸催化 剂 $\left[\mathrm{B}\left(\mathrm{C}_{6} \mathrm{~F}_{5}\right)_{3}\right]$ 与聚甲基氢硅氧烷相结合, 替代贵金属 钌、铂催化剂高效、高选择性地实现了一系列不同结 构芳香胺或脂肪胺的 $N$-甲基化反应, 并成功地将该 方法应用于药物分子布替菜芬的绿色合成, 产率高 达91\% ${ }^{[35]}$.

\section{2 烃加工与烃合成的催化科学问题}

由烃加工到烃合成, 涉及了多项新的催化反应 工艺和路线. 由 $\mathrm{C}, \mathrm{H}$ 元素组成的烃类化合物化学稳 定性和结构对称性高, 烃的催化转化组成了复杂的 反应网络, 因而解决 $\mathrm{C}-\mathrm{C}, \mathrm{C}-\mathrm{H}$ 键定位活化和择形转 化、碳碳键偶联及链增长的控制是催化研究的重要难 题. 特别是为实现由烃加工到烃合成等催化新技术 的产业化, 更需要架起从实验室(理论)到工业(工程) 的技术桥梁. 从催化工程化的角度需要解决的关键 科学问题可归纳为: “系统与基元”、“表观与本征”等 重要因素的协同.

\section{1 系统与基元一一如何在烃转化复杂反应网络 中实现选择性调变?}

烃加工与烃合成等催化反应过程均为复杂反应 网络, 反应产物分布不仅遵循化学热力学规律, 也受 到反应动力学因素的影响, 这为复杂反应网络中控 制理想的反应路径, 调控产物分布及选择性提供了 可能. 催化就是调控反应路径的重要手段, 其前提是 对复杂网络中关键基元步骤的认识及控制.

在甲醇制烯烃的烃合成过程中, 烃池反应机理 的认识对调控烯烃收率非常重要, 谢在库课题 
组 ${ }^{[36,37]}$ 提出了基于烯烃活性中心的烃池机理新模型, 构建了完整甲醇制烯烃反应网络(图 8), 并结合核磁 共振技术成功对烯烃活性中间体的存在进行了实验 验证 ${ }^{[38]}$. 基于对 MTO反应基元步骤, 特别是乙烯、丙 烯和结焦生成的活性中间体结构差异的认识, 提出 并创制了片状的SAPO-34分子篮催化剂, 应用于 MTO工业过程, 使乙烯丙烯选择性获得提高. 虽然 MTO过程稳态反应阶段的间接机理已形成广泛的共 识, 但MTO反应初期甲醇或二甲醚生成第 1 个 C-C键 反应的认知一直是 $\mathrm{C}_{1}$ 化学中极具挑战性和争议性的 课题. 刘中民课题组 ${ }^{[39]}$ 通过液氮淬冷和固体核磁表 征, 确定了催化剂上最初始反应阶段存在的表面 $\mathrm{C}_{1}$ 吸附物种和 $\mathrm{C}_{1}$ 活性物种; 进一步通过原位固体核磁 研究, 成功捕捉到二甲醚 $\mathrm{C}-\mathrm{H}$ 键活化后生成的类亚 甲氧基物种, 由此获取了 $\mathrm{C}_{1}$ 物种活化生成第一个 $\mathrm{C}-\mathrm{C}$ 键的直接证据; 并在此基础上提出了初始烯烃 生成的反应路径一一表面甲氧基/三甲基氧鎓离子协 助甲醇/二甲醚活化转化的协同反应机理. 中国科学 院山西煤炭化学研究所王建国课题组 ${ }^{[40]}$ 采用脉冲反 应、在线光谱表征和同位素标记实验等实验手段, 结 合密度泛函理论计算深人探究了甲醇转化的初始反 应过程, 发现了活性中间物种 $\mathrm{CH}_{3} \mathrm{OCH}_{2}^{+}$, 揭示了反 应初期二甲醚、 $\mathrm{CH}_{4}$ 和初始烯烃产物的形成机制, 阐 明了由 $\mathrm{C}-\mathrm{O}$ 键到 $\mathrm{C}-\mathrm{C}$ 键的转变机制, 提出了直接反应 机理一一甲氧基甲基正离子机理, 明晰了 $\mathrm{C}-\mathrm{C}$ 键的起
源, 发现初始烯烃产物为丙烯, 是“烃池”物种的来 源，实现了直接反应机理和“烃池”机理的完美对接.

在合成气转化反应中, 链增长、链终止等基元步 骤组成了复杂的反应网络 ${ }^{[41]}$. 通过反应耦合催化新 技术, 包信和课题组 ${ }^{[26,28]}$ 、王野课题组 ${ }^{[27,29]}$ 相继发展 了一系列突破 ASF规则限制的策略. 此外, 基于 $\mathrm{C}-\mathrm{C} / \mathrm{C}-\mathrm{O}$ 键选择活化的生物质水相重整制烃类燃料 过程 ${ }^{[42]}$, 复杂反应网络基元反应步骤的耦合控制也 可提高目标产品的分布.

开发烃加工和烃合成催化新路线, 其基础是对 于反应网络的理解, 通过催化反应机理的深人研究, 阐述宏观反应网络中的基元步骤及其控制原理, 发 展耦合催化反应策略, 创制新型耦合催化材料, 从而 使宏观反应系统的产品选择性得到有效调控.

\section{2 表观与本征：如何提高工业催化剂应用中的 利用效率}

工业催化剂组成较为复杂, 除体现本征反应性 能的催化材料外, 还需添加保持机械强度的惰性黏 结组分, 并制备成具有一定尺寸的颗粒，这些因素均 对反应物和产物的扩散形成影响. 工业催化剂的表 观催化性能与催化材料本征反应性能往往存在一定 差距, 因此如何实现催化材料的本征化学活性是工 业催化剂制备中需要解决的重要技术难题. 在分子 篮催化剂的烃分子转化过程中, 扩散性能直接影响

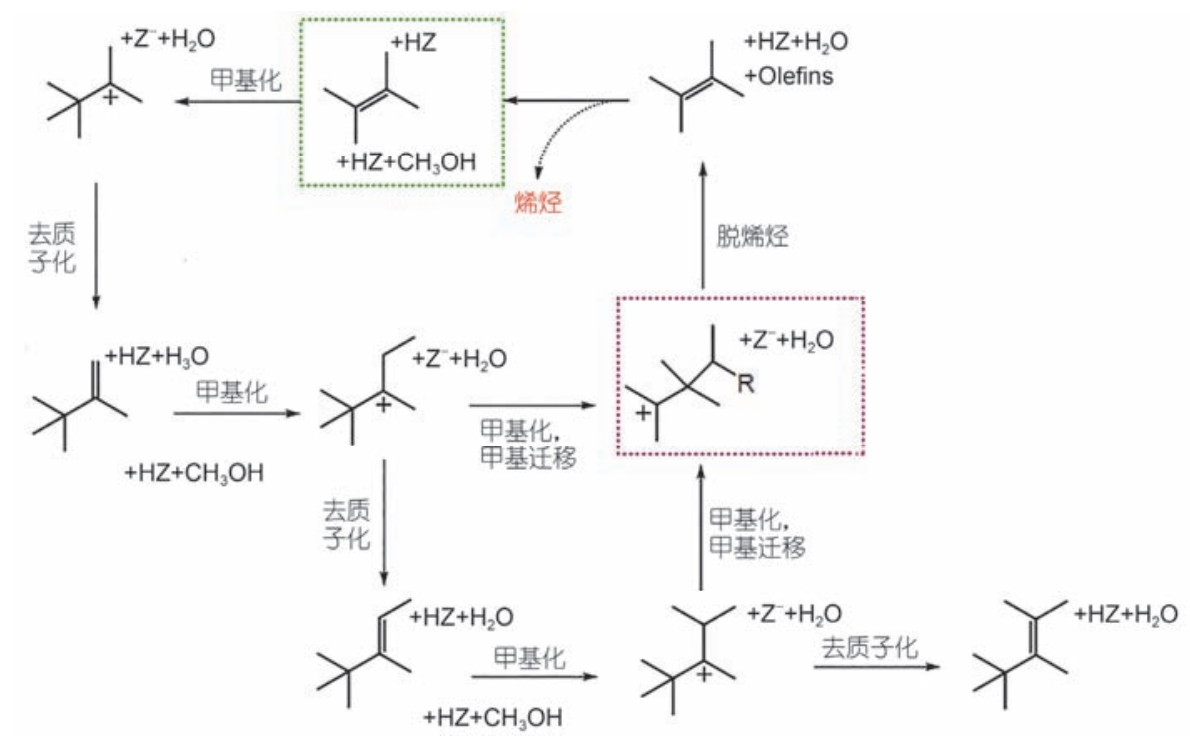

图 8 (网络版彩色)基于烯烃活性中心的甲醇制烯烃反应网络 ${ }^{[37]}$

Figure 8 (Color online) The olefin-based methanol-to-olefin reaction network ${ }^{[37]}$ 
表观反应结果, 烃分子与分子篮催化材料的孔道尺 寸相当, 分子篮孔道中构型扩散的限制会使传质受 阻, 同时在反应过程中, 反应物、反应产物, 甚至是 原料杂质也易于酸性位形成竞争吸附, 都会造成分 子篮催化剂中大量的活性中心难以接近, 而未得到 有效利用, 表观转化活性远低于其本征化学活性. 因 此, 基于扩散优势进行催化材料的设计, 提升催化剂 效率因子, 体现催化剂的本征活性, 这方面研究已成 为越来越多研究者的重要研究方向, 但目前国内外 依然缺乏全面深人的研究和切实可行的解决方法.

对于分子䇻催化剂, 提高酸中心的可及性提升 扩散优势和效率因子, 实现分子篮活性中心的本征 性能, 创制全结晶复合孔分子篮催化剂是一种有效 的解决方案. 对于生物乙醇与苯烷基化制乙苯反应, 反应过程生成水, 占据ZSM-5 分子篎催化剂部分酸 中心, 造成有效酸中心数量降低, 提高分子篎总酸量 及酸中心可及性, 可降低水的生成对催化剂性能的 影响. 上海石油化工研究院开发的全结晶复合孔分 子篮催化材料有效解决这一难题, 研究结果表明, 全 结晶复合孔分子篮催化剂的有效酸中心得到大幅提 升, 活性提高 $30 \%$ 以上, 该催化剂在 21.5 万吨/年生物
乙醇制备乙苯工业装置实现应用, 乙醇转化率大于 $99 \%$, 催化剂寿命达 2 年.

烃加工和烃合成新路线要求更加精准和高效的 催化转化, 协同催化剂表观性能与催化材料本征性 能是工业催化剂设计的重要指导思想之一, 发展反 应条件下的扩散动力学研究方法、建立高效催化剂的 分子工程方法, 是建立烃加工和烃合成催化新材料 和新工艺的重要知识体系.

\section{3 结论}

应对资源与环境的挑战, 发展先进高效的制烃 技术已成为能源化工行业的重要方向. 烃加工技术 创新的重点是发展石油资源高效利用与绿色清洁转 化催化技术; 烃合成路线制烃技术创新的近期目标 是发展甲醇及合成气转化平台等碳一转化系列技术, 促进煤、天然气高效清洁利用, 远期目标是发展生物 质资源转化及可再生能源利用技术, 最终实现碳循 环. 催化新材料创制和催化反应技术创新是发展先 进高效制烃技术的核心，其核心是解决从实验室到 工业转化中“系统与基元”、“表观与本征”等重要因素 协同的关键科学问题.

致谢本文根据第545次香山科学会议主要内容总结整理而成。“烃加工到烃合成”概念是由该次会议执行主席何鸣元院 士提出, 执行主席包信和院士、丁奎岭院士以及参加该次会议的各位科学家提出的学术思想丰富了“烃加工到烃 合成”的科学内涵. 作者感谢上述科学家对本文的贡献.

\section{参考文献}

1 Olah G, Molnár Á. Hydrocarbon Chemistry. 2nd ed. Hoboken, NJ: Wiley, 2003

2 Xiang D, Qian Y, Man Y, et al. Techno-economic analysis of the coal-to-olefins process in comparison with the oil-to-olefins process. Appl Energ, 2006, 113: 639-647

3 Ferrari D, Budroni G, Bisson L, et al. Effect of potassium addition method on $\mathrm{MoS}_{2}$ performance for the syngas to alcohol reaction. Appl Catal A Gen, 2013, 462-463: 302-309

4 Bhutto A, Qureshi K, Abro R, et al. Progress in the production of biomass-to-liquid biofuels to decarbonize the transport sector-prospects and challenges. RSC Adv, 2016, 6: 32140-32170

5 Zhang Z, Wang Q, Tripathi P, et al. Catalytic upgrading of bio-oil using 1-octene and 1-butanol over sulfonic acid resin catalysts. Green Chem, 2011, 13: 940-949

6 Shi J, Wang Y, Yang W, et al. Recent advances of pore system construction in zeolite-catalyzed chemical industry processes. Chem Soc Rev, 2015, 44: 8877-8903

7 Meng Q, Liu B, Piao J, et al. Synthesis of the composite material Y/ASA and its catalytic performance for the cracking of $n$-decane. J Catal, 2012, 290: 55-64

8 Jiao W, Wu X, Li G, et al. Core-shell zeolite $\mathrm{Y} @ \gamma-\mathrm{Al}_{2} \mathrm{O}_{3}$ nanorod composites: Optimized fluid catalytic cracking catalyst assembly for processing heavy oil. ChemCatChem, 2017, 9: 2574-2583

9 Sachse A, Garcia-Martinez J. Surfactant-templating of zeolites: From design to application. Chem Mater, 2017, 29: 3827-3853 
10 Serrano D, Escola J, Pizarro P. Synthesis strategies in the search for hierarchical zeolites. Chem Soc Rev, 2013, 42: 4004-4035

11 Ivanova I, Knyazeva E. Micro-mesoporous materials obtained by zeolite recrystallization: Synthesis, characterization and catalytic applications. Chem Soc Rev, 2013, 42: 3671-3688

12 Zhang X, Zhang F, Yan X, et al. Hydrocracking of heavy oil using zeolites Y/Al-SBA-15 composites as catalyst supports. J Porous Mat, 2008, 15: 145-150

13 Rahimi N, Karimzadeh R. Catalytic cracking of hydrocarbons over modified ZSM-5 zeolites to produce light olefins: A review. Appl Catal A Gen, 2011, 398: 1-17

14 Mitchell S, Boltz M, Liu J, et al. Engineering of ZSM-5 zeolite crystals for enhanced lifetime in the production of light olefins via 2-methyl-2-butene cracking. Catal Sci Technol, 2017, 7: 64-74

15 Teng J, Xie Z. Novel binder-less hierarchical ZSM-5 catalyst for olefins catalytic cracking to produce propylene. Sci China Chem, 2015 , 45: $533-540$

16 Zhao G, Teng J, Xie Z, et al. Effect of phosphorus on HZSM-5 catalyst for $\mathrm{C}_{4}$-olefin cracking reactions to produce propylene. J Catal, 2007, 248: 29-37

17 Wei Y L, Gao H X, Fang H, et al. Synthesis of layered structured zeolite and its catalytic performance for cumene production (in Chinese). Petrochem Technol, 2014, 43: 134-136 [魏一伦，高焕新，方华，等. 层状分子笁的合成及其在异丙苯合成中的应用. 石油化 工, 2014, 43: 134-136]

18 Tian P, Wei Y, Ye M, et al. Methanol to olefins (MTO): From fundamentals to commercialization. ACS Catal, 2015, 5: 1922-1938

19 Teng J W, Yang W M, Zhao G L, et al. Process for preparing propylene by $\mathrm{C}_{4}$ olefins catalytic cracking (in Chinese). In: Proceedings of the Seventeenth National Annual Conference on Ethylene. 2012.764-767 [滕加伟，杨为民，赵国良，等. $\mathrm{C}_{4}$ 烯烃催化裂解制丙烯技术. 见：第十七次全国乙烯年会论文集. 2012.764-767]

20 Zhang Q, Cheng K, Kang J, et al. Fischer-Tropsch catalysts for the production of hydrocarbon fuels with high selectivity. ChemSusChem, 2014, 7: 1251-1264

21 Bao J, He J, Zhang Y, et al. A core/shell catalyst produces a spatially confined effect and shape selectivity in a consecutive reaction. Angew Chem Int Ed, 2008, 120: 359-362

22 Kang J, Cheng K, Zhang L, et al. Mesoporous zeolite-supported ruthenium nanoparticles as highly selective Fischer-Tropsch catalysts for the production of $\mathrm{C}_{5}-\mathrm{C}_{11}$ isoparaffins. Angew Chem Int Ed, 2011, 123: 5306-5309

23 Cheng K, Kang J, Huang S, et al. Mesoporous $\beta$-zeolite-supported ruthenium nanoparticles for selective conversion of synthesis gas to $\mathrm{C}_{5}-\mathrm{C}_{11}$ isoparaffins. ACS Catal, 2012, 2: 441-449

24 Peng X, Cheng K, Kang J, et al. Impact of hydrogenlysis on the selectivity of the Fischer-Tropsch synthesis: Diesel fuel production over mesoporous zeolite-Y-supported cobalt nanoparticles. Angew Chem Int Ed, 2015, 127: 4636-4639

25 Zhong L, Yu F, An Y, et al. Cobalt carbide nanoprisms for direct production of lower olefins from syngas. Nature, 2016, 538: 84-87

26 Jiao F, Li J, Pan X, et al. Selective conversion of syngas to light olefins. Science, 2016, 351: 1065-1068

27 Cheng K, Gu B, Liu X, et al. Direct and highly selective conversion of synthesis gas into lower olefins: Design of a bifunctional catalyst combining methanol synthesis and carbon-carbon coupling. Angew Chem Int Ed, 2016, 55: 4725-4728

28 Jiao F, Pan X, Gong K, et al. Shape-selective zeolites promote ethylene formation from syngas via a ketene intermediate. Angew Chem Int Ed, 2018, 57: 4692-4696

29 Cheng K, Zhou W, Kang J, et al. Bifunctional catalysts for one-step conversion of syngas into aromatics with excellent selectivity and stability. Chem, 2017, 3: 334-347

30 Yang J, Pan X, Jiao F, et al. Direct conversion of syngas to aromatics. Chem Commun, 2017, 53: 11146-11149

31 Arakawa H, Aresta M, Armor J, et al. Catalysis research of relevance to carbon management: Progress, challenges, and opportunities. Chem Rev, 2001, 101: 953-996

32 Lou H, Lai H, Wu S, et al. Enhancing enzymatic hydrolysis of crystalline cellulose and lignocellulos by adding long-chain fatty alcohols. Cellulose, 2014, 21: 3361-3369

33 Li J, Huang Y B, Guo Q X, et al. Production of acetic acid from lignocellulosic biomass in the presence of mineral acid and oxygen under hydrothermal condition (in Chinese). Acta Chim Sin, 2014, 72: 1223-1227 [李江，黄耀兵，郭庆祥，等. 水热条件下酸催化氧化木质 纤维生物质制取乙酸. 化学学报, 2014, 72: 1223-1227]

34 Li J, Ding D J, Deng Li, et al. Catalytic air oxidation of biomass-derived carbohydrates to formic acid. ChemSusChem, 2012, 5: 1313-1318

35 Fu M C, Shang R, Cheng W M. Boron-catalyzed n-alkylation of amines using carboxylic acids. Angew Chem Int Ed, 2015, 54: 9042-9046

36 Wang C, Wang Y, Xie Z. Insights into the reaction mechanism of methanol-to-olefins conversion in HSAPO-34 from first principles: Are olefins themselves the dominating hydrocarbon pool species? J Catal, 2013, 301: 8-19 
37 Wang C, Wang Y, Du Y, et al. Similarities and differences between aromatic-based and olefin-based cycles in H-SAPO-34 and H-SSZ-13 for methanol-to-olefins conversion: Insights from energetic span model. Catal Sci Technol, 2015, 5: 4354-4364

38 Dai W, Wang C, Yi X, et al. Identification of tert-butyl cations in zeolite H-ZSM-5: Evidence from NMR spectroscopy and DFT calculations. Angew Chem Int Ed, 2015, 54: 8783-8786

39 Wu X, Xu S, Zhang W, et al. Direct mechanism of the first carbon-carbon bond formation in the methanol-to-hydrocarbons process. Angew Chem Int Ed, 2017, 56: 9039-9043

40 Wei Z, Chen Y, Li J, et al. Methane formation mechanism in the initial methanol-to-olefins process catalyzed by SAPO-34. Catal Sci Technol, 2016, 6: 5526-5533

41 Xiao K, Bao Z, Qi X, et al. Advances in bifunctional catalysis for higher alcohol synthesis from syngas. Chin J Catal, 2013, 34: 116-129

42 Kim Y, Dumesic J, Huber G. Aqueous-phase hydrodeoxygenation of sorbitol: A comparative study of Pt/Zr phosphate and PtReO $/$ /C. J Catal, 2013, 304: 72-85 


\title{
From hydrocarbon processing to hydrocarbon synthesis: Advances in catalytic technology
}

\author{
Zhonghao Jin ${ }^{1}$, Haibo Zhou ${ }^{1}$, Yangdong Wang ${ }^{1 *} \&$ Zaiku Xie ${ }^{2 *}$ \\ ${ }^{1}$ SINOPEC, Shanghai Research Institute of Petrochemical Technology, Shanghai 201208, China; \\ ${ }^{2}$ China Petroleum \& Chemical Corporation, Beijing 100027, China \\ * Corresponding authors, E-mail: wangyd.sshy@sinopec.com; xzk@sinopec.com
}

Hydrocarbon is a vital kind of chemical compounds to form liquid fuels and polymer monomers. It is the backbone of the national economy and is closely related to people's lives. Hydrocarbon processing refers to the production of hydrocarbon with different structures through the separation or chemical conversion of petroleum resources, such as refined petroleum products, which is a top-down way. Hydrocarbon processing, including series of chemical conversion reactions such as carbon-carbon bond cleavage, covers the major processes of petroleum refining and petrochemicals, and is the main production route for hydrocarbon products.

Hydrocarbon synthesis uses non-petroleum-based resources such as coal, natural gas, and biomass as carbon source, through chemical conversion such as carbon-carbon bond coupling and carbon chain growth. The hydrocarbon synthesis is a route that assemblies small molecules to target hydrocarbon products by bottom-up way. It covers the main processes of the new coal chemical industry and natural gas chemical industry, and is also an important component of the future biomass conversion and renewable energy industry. Hydrocarbon synthesis is an important supplement to current and future production of hydrocarbon.

But, the shortage of oil resources is inevitable. The shale gas revolution has also brought new options to the global energy economy. Facing the challenges of resource and environmental, traditional hydrocarbon production technology has been unable to meet the needs of economic development. The sustainable development of the energy and chemical industry is urgent, and the direction is clear. (1) To increase the efficiency of the use of petroleum resources to reduce energy consumption and carbon emissions. (2) The development of new hydrocarbon synthesis methods based on non-oil resources such as $\mathrm{C}_{1}$ platform reactions.

Many new catalytic reaction processes and routes are involved in hydrocarbon processing and hydrocarbon synthesis. The catalytic conversion of hydrocarbons constitutes a complex reaction network, thus solving the $\mathrm{C}-\mathrm{C}, \mathrm{C}-\mathrm{H}$ bond activation, shape-selectivity conversion, $\mathrm{C}-\mathrm{C}$ bond coupling and chain growth control is an important problem in catalytic research. In particular, in order to realize the industrialization of catalytic technologies such as hydrocarbon processing and hydrocarbon synthesis, it is necessary to build a bridge from the laboratory (theory) to the industry (engineering). The key scientific issues that need to be solved can be summarized as: synergy between important elements such as "systematic vs. elementary", and "apparent vs. intrinsic".

hydrocarbon processing, hydrocarbon synthesis, catalytic material, catalytic reaction process doi: 10.1360/N972018-00338 